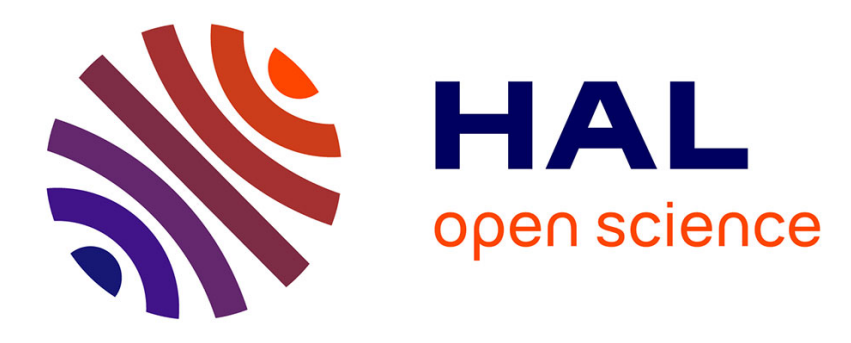

\title{
When Vowel Deletion Blurs Reduplication in Mojeño Trinitario
}

Françoise Rose

\section{To cite this version:}

Françoise Rose. When Vowel Deletion Blurs Reduplication in Mojeño Trinitario. Gale Goodwin Gómez; Hein van der Voort. Reduplication in South-American languages, Brill, 2014, 10.1163/9789004272415_015. hal-01200722

\section{HAL Id: hal-01200722 \\ https://hal.science/hal-01200722}

Submitted on 17 Sep 2015

HAL is a multi-disciplinary open access archive for the deposit and dissemination of scientific research documents, whether they are published or not. The documents may come from teaching and research institutions in France or abroad, or from public or private research centers.
L'archive ouverte pluridisciplinaire HAL, est destinée au dépôt et à la diffusion de documents scientifiques de niveau recherche, publiés ou non, émanant des établissements d'enseignement et de recherche français ou étrangers, des laboratoires publics ou privés. 


\title{
When Vowel Deletion Blurs Reduplication in Mojeño Trinitario
}

\author{
Françoise Rose
}

This paper discusses the process of verbal reduplication in the Trinitario dialect of Mojeño, an Arawak language spoken in the Bolivian lowlands. Trinitario displays partial reduplication of the verb root. Reduplication of the final syllable of the root expresses repetition or attenuation of the event expressed by the verb. This paper revises the analysis of Trinitario reduplication patterns as presented in Gill (1957), in light of additional first-hand data and the recent identification of a prosodic vowel deletion rule. It points to a phonologicallyconditioned allomorph of the basic reduplication pattern and to a second reduplication pattern implying a double copy of the final syllable of the root. The major interest of the Trinitario data is to demonstrate the great complexity of the morphology-prosody interface. The regular processes of vowel deletion and compensatory lengthening indeed affect the base only after the copy is derived, which results in a surface pattern where the copy and the base do not look alike.

This paper discusses the process of reduplication in the Trinitario dialect of Mojeño, an Arawak language spoken in the Bolivian lowlands. Trinitario displays partial reduplication of the verb root, expressing repetition or attenuation of the event expressed by the verb.

The Mojeño language (also called Moxo) consists of 4 dialects: Trinitario, Ignaciano, Loretano and Javeriano. The total Mojo population is over $\mathbf{3 2 , 0 0 0 ,}$ with around 3,220 speakers of Trinitario and Ignaciano (Crevels and Muysken 2009). Trinitario and Ignaciano are endangered dialects, while Javeriano is moribund with approximately five speakers with varying levels of proficiency. Loretano is extinct. There is a grammar of the Mojeño language as spoken in the

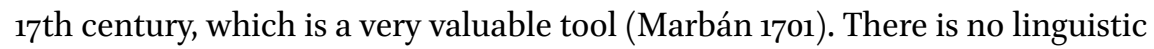
description of Javeriano and Loretano. Both Ignaciano and Trinitario have been previously described (Olza Zubiri, et al. 2002 and Gill 1957, respectively). These 
two dialects are, in general, very similar except for the pervasive vowel deletion process affecting Trinitario (Rose 2008; 2011; to appear).

In this paper, I revise the analysis of Trinitario reduplication patterns as presented in Gill (1957, 117-118), in light of the prosodic vowel deletion rule. The analysis presented in this paper is based on both the author's field data and examples given in Gill's presentation of reduplication. The field data on Trinitario was collected by the author in Trinidad and San Lorenzo de Moxos between 2005 and 2010. The resulting database consists of 30 texts consisting of approximately 2,00o sentences. Several hundred elicited sentences were added to this database. This data and Gill's work generally concur on major patterns but complement each other as far as minor patterns are concerned. This will be discussed later. All examples, mine and Gill's, are phonologically transcribed using IPA. ${ }^{1}$

After some background information on Trinitario (section 2), the functions of reduplication are presented (section 3). The remainder of the paper analyzes the details of the phonological patterns of reduplication (section 4). It first shows the basic pattern of reduplication. The influence of reduplication on stem morphology, the effect of vowel deletion, and minimality constraints are then investigated. Finally, a second pattern of reduplication is presented, where double-copy occurs. The analysis presented in this paper allows for a revision of Gill's analysis. The analysis suggested in this paper is more coherent with the overall system of the language insofar as it provides a single analysis of both stem and affix allomorphy and multiple reduplication processes. Section 5 concludes with a discussion of the ramifications of this analysis for theoretical debates concerning the morphology-prosody interface and for the typology of reduplication.

\section{Background Information on Mojeño Trinitario}

\subsection{Phonology}

The phoneme inventory of Mojeño Trinitario is presented in the following two tables.

1 My corpus is transcribed in the official alphabet (Fabricano et al. 2003), which differs from the one used by Gill. Since this paper deals with phonology, IPA is used. 
TABLE $1 \quad$ Consonants

\begin{tabular}{llllll}
\hline & Bilabial & Alveolar & Palatal & Velar & Glottal \\
\hline stops & $\mathrm{p}$ & $\mathrm{t}$ & $(\mathrm{c})$ & $\mathrm{k}$ & $\mathrm{P}$ \\
nasals & $\mathrm{m}$ & $\mathrm{n}$ & $\mathrm{n}$ & & \\
fricatives & $\beta$ & $\mathrm{s}$ & $\mathrm{c}$ & $\mathrm{x}$ & \\
affricates & & $\mathrm{ts}$ & $\mathrm{t} \int$ & & \\
approximants and tap & $\mathrm{w}$ & $\mathrm{c}$ & $\mathrm{j}$ & & \\
\hline
\end{tabular}

TABLE 2 Vowels

\section{Front vowels Central vowels Back vowels}

$\begin{array}{llll}\text { high i, i: } & & \text { u, u: } \\ \text { mid e, e: } & \text { əе, əิ: } & \text { o, o: } \\ \text { low } & & \text { a, a: } & \end{array}$

Trinitario syllable structure is either of the $(C)(C) \mathrm{V}(\mathrm{C})$ type or of the $(\mathrm{C})(\mathrm{C}) \mathrm{V}$ : type. Complex onsets and null onsets are only found word-initially. Heavy syllables (with a coda or a long vowel) are only found word-internally.

Stress normally falls on the penultimate syllable. Only a minority of CVCVCV roots are stressed on the antepenultimate syllable. Most instances of suffixation do not alter the principle of stress placement, that is to say stress automatically shifts to the right, to the penultimate syllable. Stress placement will be discussed in sections 2.3 and 4.1.

Roots generally consist of at least two syllables, to which prefixes and suffixes are added. Very few grammatical words consist of only one syllable (see section 4.4 for a discussion of minimality requirements).

\subsection{Vowel Deletion}

In this paper, "word" refers to the prosodic unit which serves as the domain of stress, vowel deletion, and morphophonological rules. In Trinitario, vowel deletion is quasi-systematic on stems of three syllables or more. ${ }^{2}$ It generally

2 Some irregularly-stressed roots resist vowel deletion. The initial vowel of disyllabic roots is not deleted when the root is word-initial. 
affects the first vowel of a prosodic word, and then every odd-numbered vowel to the right, except the final one. If the first syllable of a word is a member of a subset of person prefixes $(m a-, n i-, t a-$ or $n a-)$, the vowel of this syllable is maintained and is transparent to the vowel deletion process. Vowel deletion then affects every odd-numbered syllable to its right, except the final syllable. ${ }^{3}$

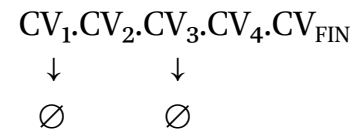

vowel deletion

$\begin{array}{lllllll}C & \mathrm{CV}_{2} & \mathrm{C} & \mathrm{CV}_{4} & \mathrm{CV}_{\text {FIN }}\end{array}$

$\mathrm{CCV}_{2} \mathrm{C} \cdot \mathrm{CV}_{4} \cdot \mathrm{CV}_{\mathrm{FIN}} \quad$ resyllabification

FIGURE 1 Rhythmic vowel deletion

This process is probably the result of historically rhythmic stress on every even-numbered syllable. In the synchronic system, stress normally falls on the penultimate syllable of the word. There are a few lexical exceptions to this rule, and certain suffixes lie outside the stress domain, i.e. they are extrametrical.

As a result of vowel deletion, almost all roots and affixes have two forms. According to their position within the prosodic word, they lose different vowels. ${ }^{4}$ Examples are given in Table 3.

TABLE $3 \quad$ Vowel deletion in Trinitario

\section{Underlying representation ${ }^{5}$ Surface representation Translation}

\begin{tabular}{lll}
\hline pokure & 'pkure & canoe \\
su-pokure & 'spokre & her canoe \\
nu-tfokojo & 'ntfokjo & I am close \\
nu-ko-tfokojo & nkotf'kojo & I got close \\
ti-ko-xuma & 'tkoxma & he/she/it is sick \\
ti-a-koxuma & tak'xuma & may he/she/it be sick
\end{tabular}

3 When $m a$ - is prefixed to a root with initial /e/ or / $\mathrm{i} /$, this sequence is realized as /mwe/.

4 Gill does not mention vowel deletion. In his work, there are two different classes of roots calling for different allomorphs of the suffixes. Once suffixed, roots change class and take different suffix allomorphs. Moreover, prefixes themselves also condition the root allomorphy.

$5 \mathrm{~V}$ represents an unspecified underlying vowel. 
In certain contexts, vowel deletion conditions compensatory vowel lengthening. Certain consonants, such as $/ \mathrm{r} /$, are not permitted in coda position. Vowel deletion strands the underlying consonant preceding this vowel. If this consonant is not permitted in coda position, it is deleted and the preceding vowel is lengthened. This process is schematized in figure 2 and exemplified with the sequence /riro/ realized /ri:/ in / poriropa / 'needle' (segments in parentheses are not directly relevant here). Table 4 illustrates cases where a vowel following $/ r /$ is dropped. This shows that $/ r /$ is deleted and a process of compensatory lengthening occurs.
$\mathrm{CV}_{1} \mathrm{rV}_{2} \quad(p o)$ riro $(p a)$
1) $\mathrm{V}_{2} \rightarrow \varnothing$
$\mathrm{CV}_{1} \mathrm{r}$
$(p) \operatorname{rir}(p a)$
vowel deletion
2) $\mathrm{r} \rightarrow \varnothing$
$\mathrm{CV}: \quad(p) r i:(p a)$ consonant deletion
$\mathrm{V}_{1} \rightarrow \mathrm{V}_{1}$ :
compensatory lengthening

FIGURE 2 Compensatory lengthening in Trinitario

TABLE 4 Compensatory lengthening in Trinitario

Underlying representation Surface representation Translation

\begin{tabular}{lll}
\hline poriropa & 'pri:pa & needle \\
su-poriropa & spo:'ropa & her needle \\
nu-xuru-ko-ri?i & nxu:'ko: $?$ i & I grow \\
nu-korVto-ko-ri?i & nko:tok'ri?i & I grab \\
\hline
\end{tabular}

It is important to note that vowel deletion and long vowels are a recent development of Trinitario. They are not found in 17th century Mojeño (Marbán 1701) nor in the Ignaciano dialect (Olza Zubiri et al., 2002).

\subsection{The Morphological Structure of the Verb}

Mojeño Trinitario is a polysynthetic language. The verb morphology is rich both at the derivational level (stem-internal) and at the inflectional level (stemexternal). As a consequence, the verb structure is morphologically complex (Figure 3), with many prefixes and suffixes. The root itself generally consists of two or three syllables. 
S-IRR-CAU-rOot RED-CLF/N-PLURAC-ACT/CAU/APL-IRR-O/MID-PL-TAM-RPT-D

FIGURE 3 Structure of the Mojeño verb

Reduplication occurs in the slot indicated in figure 3 above. The stem, delimited by the central box in figure 3 , contains one prefix slot and several suffix slots. The presence of reduplication affects two of these suffix slots, CLF and ACT, in a manner that will be specified later on. These two suffix slots are now presented.

The active suffix $(-k o \sim-t f o \sim-P o)$ is used to mark active stems. Table 5 illustrates the behavior of the active suffix with respect to the two different classes of active stems. Active verbs of the major class always carry this suffix, e.g. xano-ko. Active verbs of the minor class (all with root-final/o/, e.g. xikpo) obligatorily take the active suffix only when carrying a stem-internal suffix, like the -ri. Otherwise, when carrying no suffix or a stem-external suffix (such as $-n u$, ist singular object), they do not take the active suffix.

TABLE 5 The active suffix on the two classes of active stems

\begin{tabular}{|c|c|c|c|}
\hline Root & With no suffix & $\begin{array}{l}\text { With external- } \\
\text { stem suffix }\end{array}$ & $\begin{array}{l}\text { With internal- } \\
\text { stem suffix }\end{array}$ \\
\hline xajo & n-'xajo-ko & $c$-xajo-k(o)-nu & c-xajo-ri-ko \\
\hline 'watch' & 'I watch' & 'he/she/it watches me' & 'he/she/it always watches' \\
\hline xikpo & n-'xikpo & c-xikpo-nu & c-xikpo-ri-ko \\
\hline 'answer' & 'I answer' & 'he/she/it answers me' & 'he/she/it always answers' \\
\hline
\end{tabular}

Second, some classifiers are found within the verb stem. On stative or active intransitive verbs, they refer to the subject, as shown in (1) and (2) respectively. On transitive verbs, they refer to the object as shown in (3).

$\begin{array}{ll}\text { (1) eto } & \text { 'cxitumo. }^{6} \\ \text { eto } & \text { ti-'xitu-mo }\end{array}$

PRO3NH 3-thin-CLF:thin.flexible

'It is thin (for example, some fabric).'

6 The examples in this paper are organized in four lines: the first line represents the phonological output, the second one reflects its parsing into morphemes given in their underlying 
(2) tewarasko

ti-ewara-si-ko

3-break-CLF:round-ACT

'It broke (for example, a round stone).'

(3) njerepareko

nu-jere-pa-re-ko

'motexi

ISG-carry-CLF:grain-PLURAC-ACT earth

'I am carrying earth.'

Stem-internal suffixes (RED, classifiers and pluractional) share several properties. First, they make the active suffix obligatory on the active verbs (Compare (4) and (5)). Second, stress normally falls on the penultimate syllable of the Trinitario word (6). However, RED and classifiers are normally excluded from the stress domain. When the penultimate syllable of the word is a classifier or RED, stress therefore falls on the antepenultimate $(7) \cdot{ }^{7}$ Stress can fall on a classifier (9) only on irregular stems with antepenultimate stress such as (8). Third, stem-internal suffixes are not affected by vowel deletion, as illustrated in (10) where the /e/ or the classifier - $m e$ is expected to be deleted. ${ }^{8}$

(4) 'nomo

nu-omo

1SG-carry

'I am carrying it.'

(5) nomxiko

nu-omo-xi-ko

1SG-carry-CLF:bulk-ACT

'I am carrying it (vegetal, clothing ....).'

form, the third one represents the gloss, and the last one represents the free translation. The pervasive vowel deletion process (section 4.3) and the high number of morphophonological rules make the line with underlying forms necessary to recognize morphemes from one example to the other.

7 Stress is not systematically noted in this paper.

8 Only classifiers with an /i/ vowel are prone to vowel deletion. 
(6) 'cu:na

ti-urina

3-be.beautiful

'It is beautiful.'

(7) cu:'napa?i

ti-urina-pa?i

3-be.beautiful-CLF:ground

'The ground is clean.'

(8) n'juwako

nu-juwa-ko

1-grind-ACT

'I grind.'

(9) njuwa'meko

nu-juwa-me-ko

1-grind-CLF:flat.hard-ACT

'I grind slices of dry meat.'

(10) ttuprimeko

ti-tupuri-me-ko

3-middle-CLF:flat.hard-ACT

'in the middle of something flat and hard (a bank or a back, for example)'

\section{The Functions of Reduplication}

Verb reduplication in Trinitario is a purely morphological process that does not influence the syntactic structure of the clause. ${ }^{9}$ It never affects the argument structure of the verb, whether it is transitive or intransitive, active or not. It is purely derivational, modifying the meaning of each verb root in a regular way. In this section, the functions of reduplication as defined by Gill are presented with some additional commentary. Reduplication conveys an attenuative or frequentative meaning in Trinitario (Gill 1957, 217).

9 Olza Zubiri, et al. (2002) mention that reduplication additionally occurs on nouns, adjectives (analyzed as verbs in my work), question words, and quantifiers in the Ignaciano dialect. Concerning the Trinitario dialect, this observation is not mentioned in Gill's (1957) work. I found reduplication of these categories to be very marginal in my corpus. 


\subsection{Attenuation}

Reduplication may attenuate the meaning of the verb, with either a deintensifying or an approximative reading. In my corpus, this sense is most often found with stative predicates like the verb ixre 'be hot' in (11) and the adjective riko 'rich' in (12). It can, however, also be found on active verbs such as sopo 'believe' (13) and it(u)-ko 'know/learn' (14).

\section{(11) tixrerexi}

ti-ixVre $\sim r e-x i$

3-be.hot RED-CLF:bulk

'It is warm (medium hot).'

(12) rikkoko?o ${ }^{10}$

riko koko-?o

rich RED2 ${ }^{11}$-ACT

'He is sort of rich.'

(13) psoppoxkonu

pi-sopo po-xi-ko-nu

2SG-believe RED-CLF:bulk-ACT-1SG

'You half-believe me.'

\section{(14) mamuire 'mwettutupiko}

to $\quad$ Betfxiriwo

ma-muire 'ma-itu tutu-pi-ko

to $\quad \beta$ i-etfxiriwo

3M-too 3M-know RED2-CLF:long.flexible-ACT ART.NH 1PL-language

'He too knows a bit our language.'

\subsection{Repetition: Event-Internal Plurality}

The second meaning of reduplication in Mojeño is repetition. In my corpus, the repetitive meaning is found mostly on active verbs.

(15) najus'titixiko

na-jusVti ti-xi-ko

3PL-cut $\sim$ RED-CLF:bulk-ACT

'They chopped it.'

\footnotetext{
10 The initial vowel of disyllabic roots is not deleted when it is word-initial.

11 The double-copy pattern of reduplication shown in this example is discussed in section 4.5 .
} 

(16) ene taeßißik'ri?i

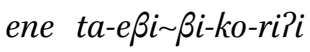
$\begin{array}{ll}\text { to } & \text { tektikwo. } \\ \text { to } & \text { tektikwo }\end{array}$
and $3 \mathrm{NH}$-swing RED-ACT-ASS ART.NH wind
'The wind makes it (a scarecrow) move.'

Reduplication with a repetitive meaning does not entail argument plurality. Examples (15) and (16) show singular subjects and singular objects with reduplicated verbs. In fact, Trinitario reduplication denotes exclusively a repetitive action within the same event frame (event-internal plurality (Cusic 1981)). It does not express the repetition of the same event at different times, with empty intervals (event-external plurality). Therefore, reduplication more specifically expresses aspect rather than verbal plurality, also called pluractionality (Newman 1990, Corbett 2000). Pluractional markers express the plurality of participants, time and/or location. In fact, a distinct pluractional marker exists in Trinitario, distinct from reduplication: the -ri suffix and its allomorphs. It most often turns the action into an activity (à la Vendler 1967), as illustrated in the example below. The pluractional verb can either affect a plurality of objects at a specific time, or be extended in time with either a durative or a habitual reading.

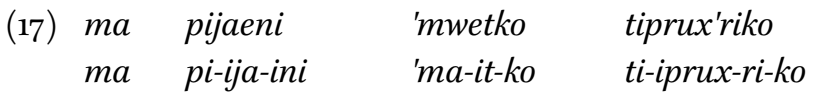

ART.M 2SG-father-PAS 3M-know-ACT 3-cure-PLURAC-ACT

'Your late father knew how to cure (people).'

\subsection{Attenuation and Repetition}

Gill states that both meanings, attenuation and repetition, can be combined in a single example, as in (18) (Gill 1957, 217). My corpus does not illustrate this. However, the translation of the reduplication process is never self-evident. The determination of the core meaning of each occurrence of reduplication is not an easy task.
(18) esu tkox'mamaxi.
esu ti-ko-xuma ma-xi
PRO.F 3-VZ-sickness RED-CLF:bulk
'She is sickly (not real sick but is often rather sick).' (Gill 1957, 217)

The two meanings conveyed by reduplication, attenuation and repetition, seem a priori divergent. Attenuation expresses a lesser degree, while repetition expresses a greater number of realizations of the event. Nevertheless, they both express a dilution of the boundaries of the event expressed by the verb: 'sickly' 
is a less clearly defined state than 'sick,' and 'chop' is a less clearly bounded event than 'cut' (being less punctual in that case). ${ }^{12}$ Attenuation and repetition are typical meanings of reduplication (Rubino 2005, 19).

\section{The Forms of Reduplication}

This section investigates the forms of Trinitario verbal reduplication, i.e. its phonological structure and its morphological status. The item (generally a root) used as a model for reduplication is called the base of reduplication in this paper. The item resulting from reduplication is called the copy.

The Trinitario reduplication process copies the last syllable of the verbal root. The copy immediately follows the root, as illustrated in (19) and (20). The copy is part of the verbal stem, as schematized in Figure 4.

(19) tmopkukuit'ritf?o

ti-mopVku ku-?i-ritfo?o

3-be.dark RED-CLF:atmosphere-still

'It is still half dark.'

(20) tema'rereko ${ }^{13}$

ti-ema're $\sim r e-k o$

3-be.lightning RED-ACT

'There is a sequence of lightning.'

CAU-root RED-CLF/N-PLURAC-ACT/CAU/APL

FIGURE 4 Mojeño verbal stem structure

The remainder of this section first discusses the position and status of the copy (4.1) and discusses its combination with the classifier $-x i$ (4.2). In section 4.3, I

\footnotetext{
12 For some discussion about these apparently divergent though related meanings of reduplication, the reader could refer to Queixalós (2002), who discusses this under the term of "distensivité."

13 I cannot explain why this root is not affected by vowel deletion. An anonymous reviewer suggests that the unexpected failure of the /a/ to delete in (20) may be due to its being a low vowel, which would by virtue of its greater sonority be less likely to delete than high or mid vowels (see note 8 ). This still needs to be checked in a larger corpus.
} 
discuss the effect of vowel deletion on the basic pattern of reduplication. The issue of reduplication of monosyllabic roots is discussed in section 4.4. Finally, a second pattern of reduplication is presented (4.5).

\subsection{The Copy as a Stem-Internal Suffix}

Since the root-final syllable and its copy are identical, there are logically two possible analyses: the copy either follows the base or is infixed before the final syllable. The first analysis is more economical since the copy would be considered a suffix immediately adjacent to the root rather than an infix for which a slot within the root would be added. This analysis is supported by the morphology of reduplicated stems. The copy shows a behavior typical of stem-internal suffixes (see 2.3). First, it causes the active suffix to be obligatory on all active stems, just as stem-internal suffixes do. This is the case with the verbs amo 'swell up' and soko 'defecate,' which do not take the active suffix in the absence of a stem-internal suffix. In (21), the presence of the active suffix -ko can only be attributed to the reduplication process. In (22), it can be attributed to the classifier - $x i$ 'bulk' as well. See also example (5) where the active suffix is induced by a classifier on a non-reduplicated root.

\section{(21) Bjammo?ojore}

Bi-amo mo-?o-jore

1PL-swell.up RED-ACT-FUT

'We are going to swell up.'

(22) tsokkox'kojre

ti-soko ko-xi-ko-jore

3-defecate RED-CLF:bulk-ACT-FUT

'(S)he has diarrhea.'

Second, on regular roots, the copy is transparent for stress. The position of stress is calculated as if the copy were absent (23). Like other stem-internal suffixes, the copy can be stressed on irregularly stressed roots, like kémtone in (24).

(23) tema'rereko ${ }^{14}$

ti-ema're $r e-k o$

3-be.lightning RED-ACT

'There is a sequence of lightnings.'

14 I cannot explain why this root is not affected by vowel deletion. 
(24) nkemton'nekpo

nu-ko-emotone ne-ko-po

ISG-VZ-work RED-ACT-PERF

'I worked there and there.'

Third, the copy always conserves its vowel. Thus, in example (25), the first and third vowels are deleted. The fifth vowel, while expected to be deleted, is maintained because it is the vowel of the copy. We will return to this below.

(25) tixrerexi

ti-ixVre $\sim r e-x i$

3-be.hot RED-CLF:bulk

'It is warm (medium hot).'

These three properties of the copy argue strongly that it is a stem-internal suffix.

\subsection{Reduplication and $-x i$}

The reduplicated stem is very frequently followed by the classifier $-x i \sim-x$ 'bulk, $^{\prime}$ inserted after the copy (and before the active suffix on active verbs). It is not obligatory, but most occurrences of reduplication show it, as in (26) and (27).

(26) tkox'mamaxi

ti-ko-xuma ma-xi

3-VZ-sickness $\sim$ RED-CLF:bulk

'(S)he is sickly.'

(27) najus'titixiko

na-jusV'ti ti-xi-ko

3PL-cut $\sim$ RED-CLF:bulk-ACT

'They chopped it.'

$-x i \sim-x$ is one of the classifiers described in 2.3. Its semantics are not easy to define. Gill offers the following definition: "-xi denotes usually bulky soft objects (grass, leaves, small branches, fresh meat, any cloth material, pillow; also mud, garbage; also clouds)" (Gill 1957, 84). Examples are given below.

(28) nsu:xiko

nu-suCV-xi-ko

1SG-fry-CLF:bulk-ACT

'I fry (fresh meat).' (Gill 1957, 84) 


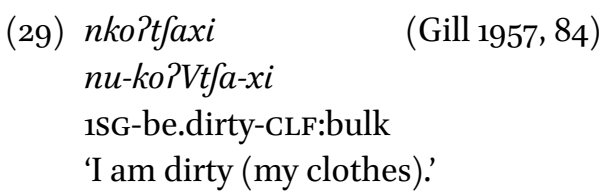

The use of $-x i$ along with reduplication departs from Gill's definition given above. In some examples, like the ones below, there is no bulky object it could refer to in an obvious way.

(30) esu seno 'somuire cu:'nanaxi

esu seno 'su-omuire ti-uri'na na-xi

PRO3F lady 3 F-also 3-be.beautiful RED-CLF:bulk

'This lady is also beautiful.'

$\begin{array}{lll}\text { (31) mwestataxiko } & \text { to } & \text { wije } \\ \text { ma-esta } \text { ta-xi-ko } & \text { to } & \text { wije }\end{array}$

3M-whisp RED-CLF:bulk-ACT ART.NH ox

'He often hits the ox.' (Gill 1957, 218)

For this reason, Gill considers - $x i$ to be "part of the reduplication morpheme," but still considers it an object classifier in some examples, specifically when it retains its full meaning. I consider it a morpheme separate from the copy. On the morphological level, it fills the classifier slot like other classifiers do (see (32) and (33)). Moreover, there are no examples of a reduplicated stem with $-x i$ that combines with some other classifier.

(32) tixreremo

ti-ixre $\sim$ re-mo

3-be.hot RED-CLF:flat.flexible

'It is medium hot (of something flat and flexible, like a pancake).' (elicited)

(33) neße'roroçe?o

ni-eße'ro ro-çe-?o

3M-lick RED-CLF:bone-ACT

'He licked the bones.'

Yet the meaning of the $-x i$ classifier on reduplicated verbal roots is often bleached. Its use has become generalized in such a way that it resembles the fixed segmentism that occurs with reduplication in some languages. Alderete, et al. (1999) distinguish two types of fixed segmentism: phonological fixed seg- 
mentism occurs when the presence of a default segment is phonologically motivated, and morphological fixed segmentism occurs when an affix is attached to the base concomitant with reduplication. The Trinitario $-x i$ could be analyzed as a type of optional morphological fixed segmentism since it is not phonologically motivated.

\subsection{Taking Vowel Deletion into Account}

A surface variant of the basic reduplication pattern occurs in Trinitario. This is not explained in Gill's work. The process of vowel deletion may have the effect of deleting the final vowel of the root in the reduplicated form of the verb, as illustrated in (34) and (35). This occurs if the root-final vowel is in an odd-numbered syllable of the underlying structure of the word. Since the copy is suffixed to the root (consonant-final in those cases), reduplication surfaces in these cases as a sequence of two identical consonants. As a result, the identity between the copy and the base is not transparent in the phonological output.

(34) viammo?ojre

vi-amo mo-Po-jore

1PL-Swell RED-ACT-FUT

'We are going to swell.'

(35) tjuxpanniko

ti-juxVpani ni-ko

3-ask.favor RED-ACT

'(S)he keeps asking for favors.'

This allomorphy does not constitute a different reduplication pattern. The alternation is predictable. This sequence of identical consonants cannot be analyzed as simple consonant reduplication. (36a) exemplifies the syllabic reduplication pattern on the root sopo 'believe.' /po/ is copied, and vowel deletion normally affects the first, third, and fifth syllables of the word. The rootfinal /o/ is deleted, being the third vowel of the word. As a result, the two $/ p /$ consonants are adjacent. The sequence of identical consonants is created by the deletion of the vowel between the two successive consonants in the rootfinal syllable and the copy, these two being similar due to the reduplication process. (36b) illustrates the single-consonant reduplication analysis, applied to the same root. If $/ \mathrm{p} /$ only was doubled, the initial $/ \mathrm{i} /$, the root-final $/ \mathrm{o} /$ and the $/ \mathrm{o} /$ of $-k$ o should be deleted, since vowel deletion affects the vowels of odd-numbered syllables within the word. The resulting phonological output is incorrect. 
(36a) psoppoxkonu

pi-sopo po-xi-ko-nu

2SG-believe RED-CLF:bulk-ACT-1SG

'You half-believe me.'

(36b) "psoppxiknu

*pi-sopo $\langle\sim p\rangle-x i-k o-n u$

2SG-believe RED-CLF:bulk-ACT-1SG

'You half-believe me.'

Vowel deletion can also lead to compensatory lengthening in reduplicated stems if the stranded consonant is not allowed in coda position. This is the case with $/ \mathrm{r} /$ in $(37)$ and $/ \mathrm{w} /$ in $(38)$.

(37) matfa:re'puekpo "matfarrepuekpo

ma-'tfare $\sim r e-p u e-k o-p o$

3M-pull.up RED-CLF:ground-ACT-PERF

'He pulled them up.'

(38) tçi:'woxi

${ }^{*} t c ̧ i w ' w o x i$

ti-çiwo wo-xi

3-rain RED-CLF:bulk

'rainy season (it rains repeatedly)'

When a reduplicated stem undergoes both vowel deletion and compensatory lengthening, the base and the copy appear distinct at the surface level (compare $/ t f a: /$ and / re/ in (37) and /çi:/ and / wo/ in (38)).

\subsection{Reduplication and Monosyllabic Roots}

In one example, the reduplicated syllable is arguably the last syllable of the stem, rather than the last syllable of the root. The parsing of this form is discussed a bit further below.

(39) Bnikkoxko

ßi-ni-ko ko-xi-ko

1PL-eat-ACT RED-CLF:bulk-ACT

'We eat often.'

The root $n i$ 'eat' is one of the few monosyllabic verbal roots. There are some external reasons to believe that the base niko is composed of the root $n i$ 'to eat,' 
and the active suffix $-k o$ (40). For example,-ru is a nominalizing suffix which regularly replaces the active suffix on active verbs. On the verb 'to eat,' -ko is replaced by $-r u(41)$. Moreover, example (42) shows that a classifier can be inserted between $n i$ and $-k o$.

(40) nniko

nu-ni-ko

1SG-eat-ACT

'I eat.'

(41) to naniru

to $\quad$ na-ni-ru

ART.NH 3PL-eat-PAT.NZ

'their food'

(42) tanitfeko

ta-ni-te-ko

to juku

3NH-eat-CLF:flat.bounded-ACT ART.NH fire

'The fire burnt the board.' (elicited)

In (39), it is thus the active suffix rather than the final syllable of the root that is reduplicated. This suffix is considered part of the reduplicative base. This can be explained via the minimality restrictions. Within the Theory of Prosodic Morphology, McCarthy and Prince (1995, 321-325) state that a "prosodic word" must contain at least one foot, i.e. two moras or syllables, according to whether the language is quantity-sensitive or not. Spring (1990, 140-163, cited in McCarthy and Prince 2001) studied reduplication in Axininca Campa, an Arawak language of Peru. She proposes that the base of reduplication is a prosodic word. Since all prosodic words must be bimoraic in this language, monomoraic bases must be augmented for reduplication to apply. Considering this, a possible analysis of example (39) is that there is a constraint in Trinitario on the size of the base: it must be bisyllabic or bimoraic. Reduplication cannot affect the monosyllabic root $n i$ in a regular way because it is subminimal. The suffix following the root is included in the base in order to make it bisyllabic. Then, reduplication copies the final syllable of the base in a regular fashion, but this base-final syllable happens to be a suffix. The copy is immediately followed by the classifier $-x i$ and an additional active suffix. This suggests that the original active suffix following the root was reanalyzed as part of the base in the reduplication process. 
An elicitation session conducted to collect additional examples of monosyllabic (and monomoraic) root reduplication did not produce any reduplicated form for the roots no 'put' and $\beta e$ 'take.' However, the monosyllabic root tse 'to be ready' was found to be reduplicable without any sensitivity to minimality. The question of base minimality therefore remains open.

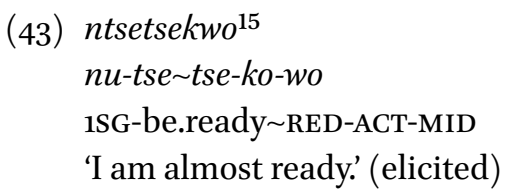

Gill claims that in Trinitario, "on words of only one or two syllables AND on Initial Subjunctive words [a class of stative roots which mark the irrealis with a prefix rather than a suffix] the last syllable of the stem or word itself is repeated." (Gill 1957, 218). He then provides five examples. In my view, only the example repeated in (39) and discussed above constitutes a possible counterexample to the fact that reduplication affects the last syllable of the root. I suggested that it could be explained via minimality constraints. The four other examples concern the trisyllabic derived root kó-t $f$ it $f a$ 'to have children' and the bisyllabic active roots ero 'to drink,' sopo 'to believe,' and u:na 'to be good. ${ }^{16}$ In all four of these, the last syllable of the root is normally reduplicated.

\subsection{The Double-Copy Pattern}

In some examples, such as (44), (45) and (46), reduplication results in a surface form where apparently, the final consonant of the root is doubled and the root is followed by a copy of the final syllable. In my analysis, the root-final syllable is copied twice while deleting the root-final vowel (...C)VC $\varnothing \sim \mathrm{CVCV}$. This constitutes a second pattern of reduplication which could be labeled double-copy or triplication, and I have glossed it as 'RED2.'

\footnotetext{
15 There is no interest in analyzing this example as a case of full reduplication since full reduplication would then be restricted to monosyllabic verbs which show reduplication of the root. It is much more economical to explain this copy of the root as a monosyllabic reduplication of the final (and here, unique) syllable of the root. There is no pattern of full reduplication in Mojeño Trinitario.

16 There are good arguments to synchronically consider $u$ :na a bisyllabic root resulting from the lexicalization of uri 'good' and the human classifier -na.
} 
(44) Ptum'memexi

Ptume meme-xi

valiant $\sim$ RED2-CLF:bulk

'He is always ready.'17 (Gill 1957, 217)

(45) mamuire 'mwettutupiko

to $\quad$ Betfxiriwo

ma-omuire ma-it(u) tutu-pi-ko

to $\quad \beta$ i-etfxiriwo

3M-also $3 \mathrm{M}$-know RED2-CLF:long.flexible-ACT ART.NH 1PL-language

'He too knows a bit of our language.'

(46) eni rikkoko?o

eni riko koko-?o

PRO.M rich RED2-ACT

'He is sort of rich.' (elicited)

This type of reduplication was first identified by Gill (1957). However, Gill does not consider it a second pattern of reduplication. His analysis refers to the basic reduplication pattern, i.e. a unique copy of the root-final syllable, with additional morphophonemic changes in the base (consonant doubling). However, his analysis predicts incorrect vowel deletion. (47a) illustrates the double-copy analysis and correctly predicts that the initial /i/, the rootfinal $/ \mathrm{u} /$ and the $/ \mathrm{o} /$ of $-k o$ are deleted. The last vowel of the double-copy is unaffected by vowel deletion but is transparent. As shown in 2.2, this property is shared with other stem-internal suffixes, such as classifiers. ( $47 \mathrm{~b}$ ) illustrates the analysis of single-consonant reduplication. It shows that were the final consonant of the root itu 'learn' doubled, the initial /i/, the root-final $/ \mathrm{u} /$, and the $/ \mathrm{i} /$ of - pi would be deleted, being the first, third and fifth vowels of the underlying structure of the word. The resulting phonological output is incorrect. One must therefore reject the consonant doubling analysis. ${ }^{18}$

17 I elicited this translation for the reduplicated form given in Gill (1957). The root means 'to be valiant, to be strong, to be motivated.'

18 Apart from the application of vowel deletion, there are other problems with this analysis. First, there is no obvious explanation for consonant doubling. As we have shown in 4.3, examples of apparent consonant doubling can be better explained by vowel deletion, a process pervasive in the language. Second, this analysis links consonant doubling with an additional copy of the root-final syllable. We have shown that the so-called consonant doubling can occur without an additional copy. 
(47a)esu sittutupik'ripo to

esu su-itu tutu-pi-ko-ripo to

PRO.3F 3F-learn RED2-CLF:long.flexible-ACT-already ART.NH

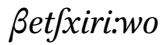

Bi-etfxiri:wo.

1PL-language

'She is learning our language bit by bit.'

(47b)* sitttupkoripo

*su-itu $\langle\sim t\rangle \sim t u$-pi-ko-ripo

3 F-learn $\sim$ RED RED-CLF:long.flexible-ACT-already

'She is learning a language bit by bit.'

It remains an open question as to whether the double-copy is an allomorph of the basic reduplication pattern when it is applied to roots with final vowel deletion or whether it constitutes an independent pattern with its own meaning. In the pair of examples below, (49) differs from (48) both in the pattern of reduplication used and in the presence of an additional prefix: (48) uses the basic reduplication pattern, while (49) uses the double-copy pattern.

(48) tkox'mamaxi

ti-ko-xuma ma-xi

3-VZ-sickness $\sim$ RED-CLF:bulk

'He is always sick.' (elicited)

(49) wo takxum'mamaxi

wo ti-a-ko-xuma mama-xi

NEG 3-IRR-VZ-sickness $\sim$ RED2-CLF:bulk

'He is not always sick.' (elicited)

The comparison of these two examples supports the idea that the second reduplication pattern is related to vowel deletion. In (48), where the rootfinal vowel $V_{4}$ is not deleted, basic reduplication is used. In (49), where the presence of an additional prefix triggers deletion of the root-final vowel $V_{5}$, reduplication occurs with a double-copy. The relationship between doublecopy and root-final vowel deletion is also supported by the lack of a doublecopy pattern in the Ignaciano dialect. Ignaciano does not undergo vowel deletion.

This double-copy pattern occurs on roots where the final vowel is in the third or fifth syllable of the underlying structure of the word, i.e. in the same 
context where vowel deletion occurs on basic reduplication, as presented in 4.3. One possible explanation for this pattern is that the presence of a second copy is used to compensate for the loss of similarity between the base and the copy due to vowel deletion. The second copy recreates a sequence of two identical syllables. Surface level opacity would thus feed morphological doubling, and the use of the double-copy pattern would be due to the prosodic environment.

Both the basic pattern with a unique copy of the last syllable and the doublecopy pattern can occur on some roots, with a slightly different meaning. This alternative between the two reduplication patterns is not productive. ${ }^{19}$

(50) ßjammo?o

$\beta i$-amo mo-?o

1PL-swell.up RED-ACT

'We are swollen up (in a body-part).' (elicited)

(51) ßjam'momo?o

$\beta i$-amo momo-?o

1PL-swell.up RED2-ACT

'We are swollen up (all over).' (elicited)

(52) sittupko

su-itu tu-pi-ko

3F-learn RED-CLF:long.flexible-ACT

'She is learning (a language) a little.' (elicited)

(53) esu sittutupik'ripo to

esu su-itu tutu-pi-ko-ripo to

PRO.3F 3F-learn RED2-CLF:long.flexible-ACT-already ART.NH

ßetfxiri:wo.

Bi-etfxiri:wo

1PL-language

'She is learning our language bit by bit.'

19 Speakers accepted neither the double-copy on the roots kemtone and soko (illustrated in (24) and (22) with the basic reduplication pattern), nor the basic pattern of reduplication on the roots riko and Ptume (illustrated in (46) and (44) with double-copy). 
(54) $\beta k o t \int i t t \int a x i^{20}$

$\beta i-k o-t \int t f a \sim t f a-x i$

1PL-VZ-children $\sim$ RED-CLF:bulk

'We have many children.' (Gill 1957, 217)

(55) tkotfittfatfaxi

ti-ko-t $\int \mathrm{t} t \int a \sim t \int a t \int a-x i$

3-VZ-children RED2-CLF:bulk

'He has many children with various women.' (elicited)

In the examples above, the two phonological patterns (basic and double-copy) seem to convey different degrees in the reduplication meaning. They do not individually correspond with the two major semantic functions of Trinitario reduplication discussed in section 3 (attenuation and repetition). ${ }^{21}$ It rather seems that the double-copy pattern can be used to intensify the meaning of reduplication, whether attenuation as in (50) and (51) or repetition, as in (52) and (53). This suggests that the double-copy is not an allomorph of the basic reduplication pattern. A similar correlation between multiple copy and intensification of the meaning of reduplication is attested elsewhere. For example, in Tigre (Semitic, Erytrea), reduplication conveys attenuation. The number of copies goes from one to three. The greater the number of copies, the more attenuated the meaning of the verb is (S. Rose 2003, 113). It remains an open question as to whether the double-copy could be found independently of rootfinal vowel deletion.

\section{$5 \quad$ Conclusion}

This paper describes verbal reduplication in Trinitario. At the semantic level, partial reduplication of the verb conveys either an attenuative or a repetitive meaning. At the morphological level, the copy is a derivational suffix internal to the stem. At the phonological level, Trinitario reduplication involves copying the root-final syllable, with a possible double-copy of the same syllable. The base may be altered by vowel deletion and compensatory lengthening.

\footnotetext{
$20 \quad / \mathrm{t} f /$ is realized as $/ \mathrm{t} /$ before another $/ \mathrm{t} /$.

21 In Tupi-Guarani languages, each phonological template expresses a different meaning (Rose 2005, 2007).
} 
With the help of a new Trinitario corpus and better knowledge of the phonological evolution of this dialect, a better understanding of the reduplication process was reached. This paper put forward two new analyses. First, Trinitario contains a phonologically-conditioned allomorph of the basic reduplication pattern, previously described by Gill (1957), that surfaces as consonant doubling. Second, there is a second reduplication pattern, where two copies of the root-final syllable occur and the root-final vowel is deleted. These patterns are explained as recent historical developments resulting from the pervasive vowel deletion process in the Trinitario dialect. Taking vowel deletion into account in the analysis here lets us explain the surface variants of various reduplication patterns in a manner that coheres better with the general prosodic system of the language.

At the theoretical level, data on reduplication have nourished debates on the morphology-prosody interface. Among others, reduplication in the Arawak language Axininca Campa has triggered recent developments in prosodic morphology within Optimality Theory (McCarthy and Prince 1993; 2001). Without entering this theoretical topic, the Trinitario data demonstrate the great complexity of the morphology-prosody interface. First, the reduplication morpheme (the copy) is defined in prosodic terms (one or two syllables). Second, the base is defined morphologically (as the root) and prosodically (possibly as a "minimal word"). Finally, the prosodic process of vowel deletion applies only after reduplication. The form of the copy is determined by the underlying form of the base, before any prosodic operation applies.

At the typological level, the fact that Trinitario displays partial reduplication (copying part of an element), but no full reduplication, is a clear counterexample to the hypothesis that "all languages that have partial reduplication also have total reduplication" (Moravcsik 1978, 328; Rubino 2005, 12). Another interesting aspect of Trinitario reduplication is that the regular processes of vowel deletion and compensatory lengthening result in a surface pattern where the copy and the base do not look alike. Differences between the base and the copy are usually attributed to phonological processes affecting the copy (Rubino 2005,17 ). In Trinitario, it is the base that is altered by the vowel deletion and other prosodic rules, making the normally transparent phonological identity between base and copy opaque.

\section{Acknowledgments}

This paper has benefited very much from commentary by Christian DiCanio, Gérard Philippson, the editors, and an anonymous reviewer. 


\section{References}

Alderete, John, Jill Beckman, Laura Benua, Amalia Gnanadesikan, John McCarthy, and Suzanne Urbanczyk. 1999. Reduplication with fixed segmentism. Linguistic Inquiry 30: $327-364$.

Corbett, Greville. 200o. Number. Cambridge: Cambridge University Press.

Crevels, Mily, and Pieter Muysken. 2009. Lenguas de Bolivia: presentación y antecedentes. In Lenguas de Bolivia, Tomo I: Ámbito andino, ed. Mily Crevels and Pieter Muysken, 13-26. La Paz: Plural editores.

Cusic, David D. 1981. Verbal plurality and aspect. PhD diss., Stanford University.

Fabricano Noé, Felicia, Justo Semo Guají, and Janneth Olivio. 2003. Guía del alfabeto mojeño trinitario. La Paz: Ministerio de Educación de Bolivia.

Gill, Wayne. 1957. Trinitario grammar. Manuscript. San Lorenzo de Mojos: Misión Nuevas Tribus.

Hurch, Bernhard, with Veronika Mattes, ed. 2005. Studies on reduplication. [Empirical Approaches to Language Typology 28]. Berlin/New York: Mouton de Gruyter.

Marbán, Pedro. 1701. Arte de la lengua Moxa, con su Vocabulario, y Cathecismo. Lima.

McCarthy, John, and Alan Prince. 1995. Prosodic morphology. In The handbook of phonological theory, ed. John Goldsmith, 318-366. Cambridge: Blackwell.

- 2001 [1993]. Prosodic morphology: Constraint interaction and satisfaction. Manuscript.

- 1993. Generalized alignment. In Yearbook of Morphology: 79-153.

Moravcsik, Edith. 1978. Reduplicative constructions. In Universals of human language, ed. Joseph Greenberg, 297-334. Stanford: Stanford University Press.

Newman, Paul. 1990. Nominal and verbal plurality in Chadic, Publications in African languages and linguistics 12. Dordrecht: Foris

Olza Zubiri, Jesús, Conchita Nuni de Chapi, and Juan Tube. 2002. Gramática Moja Ignaciana. Caracas: Universidad Catolica Andres Bello.

Ott, Willis, and Rebecca Ott. 1983. Diccionario ignaciano y castellano, con apuntes gramaticales. Cochabamba: Instituto Lingüístico de Verano.

Queixalós, Francesc. 2002. Sur la distensivité. Mémoires de la Société de Linguistique de Paris XII, La pluralité: $55^{-71 .}$

Rose, Françoise. 2005. Reduplication in Tupi-Guarani languages: Going into opposite directions. In Hurch (ed.), 351-368.

2007. Action répétitive et action répétée: Aspect et pluralité verbale dans la réduplication en émérillon. Faits de Langues 29, La réduplication: 125-143.

- 2008. The word-prosodic system of Mojeño Trinitario and pervasive vowel deletion. Paper presented at A Estrutura de Línguas Amazônicas: Fonologia e Gramática II, November 24 in Recife, Brazil. 
- 2011. Morphological and prosodic structure of the Trinitario verb. Paper presented at the Americanist meeting: Word-formation in South American languages, June 24, in Leipzig, Germany.

. to appear. Mojeño trinitario. In Lenguas de Bolivia, Tomo III: Oriente, ed. Mily Crevels and Pieter Muysken. La Paz: Plural editores.

Rose, Sharon. 2003. Triple take: Tigre and the case of internal reduplication. San Diego Linguistic Papers 1: 109-128.

Rubino, Carl. 2005. Reduplication: Form, function and distribution. In Hurch (ed.), 11-29.

Spring, Cari. 1990. Implications of Axininca Campa for prosodic morphology and reduplication. PhD diss., Tucson: University of Arizona.

Vendler, Zeno. 1967. Linguistics and philosophy. Ithaca/NewYork: Cornell University Press.

\section{Abbreviations}

$\begin{array}{llll}\text { ACT } & \text { active } & \text { O } & \text { object } \\ \text { APL } & \text { applicative } & \text { PAS } & \text { past } \\ \text { ART } & \text { article } & \text { PAT.NZ } & \text { patient nominalizer } \\ \text { CAU } & \text { causative } & \text { PL } & \text { plural } \\ \text { CLF } & \text { classifier } & \text { PLURAC } & \text { pluractional } \\ \text { COP } & \text { copula } & \text { PRO } & \text { pronoun } \\ \text { D } & \text { discourse marker } & \text { RED } & \text { reduplication } \\ \text { F } & \text { feminine (singular) } & \text { RED2 } & \text { double reduplication } \\ \text { FUT } & \text { future } & \text { RPT } & \text { reportative } \\ \text { IRR } & \text { irrealis } & \text { S } & \text { subject } \\ \text { M } & \text { masculine (singular) } & \text { SG } & \text { singular } \\ \text { MID } & \text { middle } & \text { TAM } & \text { Tense-Aspect-Mood } \\ \text { N } & \text { (incorporated) noun } & \text { VZ } & \text { verbalizer } \\ \text { NH } & \text { non-human } & & \end{array}$

